\title{
BYCATCH OF FRANCISCANA DOLPHINS PONTOPORIA BLAINVILLEI AND THE DYNAMIC OF ARTISANAL FISHERIES IN THE SPECIES' SOUTHERNMOST AREA OF DISTRIBUTION
}

\author{
María Fernanda Negri ${ }^{l}$, Pablo Denuncio ${ }^{2}$, María Victoria Panebianco ${ }^{l}$ and Humberto Luis Cappozzo ${ }^{I}$ \\ ${ }^{1}$ Laboratorio de Ecología, Comportamiento y Mamíferos Marinos, \\ Museo Argentino de Ciencias Naturales "Bernardino Rivadavia" (CONICET) \\ (Av. Ángel Gallardo 470 (C1405DJR), Buenos Aires, Argentina) \\ ${ }^{2}$ Universidad Nacional de Mar del Plata \\ Instituto de Investigaciones Marinas y Costeras, Facultad de Ciencias Exactas y Naturales,
} (Funes 3350 (7600), Mar del Plata, Argentina)

*Corresponding author: mariafernandanegri@gmail.com

\section{A B S T R A C T}

\begin{abstract}
In Argentina, the franciscana dolphin is one of the most vulnerable cetaceans regularly entangled in coastal artisanal fishery nets. The aim of this paper is to estimate the species' incidental mortality on the Southern coast of Buenos Aires province through interviews with the captains of artisanal fishing vessels, in the period 2006-2009. Franciscana bycatch was reported for gillnets and shrimper gear all year round but it occurred more frequently between October and February, at $5 \mathrm{~km}$ offshore and 10$20 \mathrm{~m}$ depth. The estimated mean annual incidental mortality was 107 dolphins $($ CI 95\% = 87-129), 92 caught in gillnets $(\mathrm{CI} 95 \%=73-112)$ and 15 in shrimpers' gear $(\mathrm{CI} 95 \%=8-25)$ with a capture per unit effort of 0.029 dolphins per km of gillnet $(\mathrm{CI} 95 \%=0.023-0.036)$ and 0.022 per shrimpe r's net (CI 95\% = 0.012-0.035). Annual fluctuations were due to differences in the number of gillnetting fishing days. If mortality estimates for the Northern coast are also taken into account, values attain a maximum of 360-539 dolphins bycaught in the entire Buenos Aires province, representing 2.5-3.7\% of the species' abundance in Argentina. This will inevitably lead to the decline of franciscana dolphin populations in the near future unless alternative fishing grounds are identified and alternative gearadopted.
\end{abstract}

\section{RESUMO}

$\mathrm{Na}$ Argentina, a toninha é um dos cetáceos mais vulneráveis devido às capturas por rede de pesca artesanal. O presente estudo teve como objetivo estimar as capturas acidentais no sul da província de Buenos Aires, através de entrevistas aos capitães de barcos de pesca artesanal, entre os anos 20062009. As capturas foram reportadas para redes de emalhe e de camarão; com as mais altas frequências entre outubro e fevereiro, a $5 \mathrm{~km}$ da costa e $10-20 \mathrm{~m}$ de profundidade. A mortalidade acidental média anual estimada foi de 107 golfinhos (IC 95\% = 87-129), 92 em redes de emalhe (IC $95 \%=73-112$ ) e 15 em redes de camarão (IC 95\% = 8-25), com uma captura de 0,029 golfinhos $/ \mathrm{km}$ de rede de emalhe (IC 95\% =0,023-0,036) e 0,024/rede de camarão (IC 95\% =0,012-0,035). As flutuações anuais responderam principalmente às diferenças nos dias de pesca. Considerando o último levantamento estimativo feito para o norte costeiro da província, estima-se uma mortalidade entre 360-539 golfinhos/ano em toda a província de Buenos Aires. Esses valores correspondem de 2,5-3,7\% da abundância populacional da Argentina; o que traria como consequência um declínio populacional da espécie, tornando-se fundamental encontrar alternativas de pesca para a área.

Descriptors: Franciscana dolphin, Pontoporia blainvillei, Incidental mortality, Artisanal fisheries, Southwestern Atlantic Ocean.

Descritores: Toninha, Pontoporia blainvillei, Capturas acidentais, Pesca artesanal, Atlântico SulOcidental,

\section{INTRODUCTION}

Thousands of cetaceans are bycaught in gillnet fisheries worldwide (BEARZI, 2002; PERRIN et al., 1994; SHIGUETO et al., 2008; MANGEL et al.,
2010). They are mostly small coastal dolphins belonging to species of the genera Phocoena, Tursiops, Sousa and Delphinus, and almost all river dolphins (PERRIN et al., 1994; REEVES; LEATHERWOOD, 1994; READ, 1996). 
In Argentina, the franciscana dolphin Pontoporia blainvillei and Commerson's dolphin Cephalorhynchus commersonni are the most vulnerable cetaceans regularly entangled in artisanal fishery nets due to their coastal distribution (CRESPO et al., 1994; IÑIGUEZ et al., 2003). The franciscana dolphin inhabits coastal waters of the Southwestern Atlantic Ocean, from Espírito Santo, Brazil (18 $25^{\prime} \mathrm{S}$, $\left.30^{\circ} 42^{\prime} \mathrm{W}\right)$, to Chubut, Argentina $\left(42^{\circ} 35^{\prime} \mathrm{S}, 64^{\circ} 48^{\prime} \mathrm{W}\right)$ (SICILIANO, 1994; CRESPO et al., 1998; BASTIDA et al., 2007). Since 2008, it has been included in the category "vulnerable" to extinction by the International Union for the Conservation of Nature (REEVES et al., 2008), mainly because of the high levels of bycatch that this species has faced over the last two decades throughout its area of distribution (ROSAS et al., 2002; DI BENEDITTO, 2003; SECCHI et al., 2004; CAPPOZZO et al., 2007; FRANCO-TRECU et al., 2009). Moreover, some of the prey items of the franciscana dolphin, such as the croacker Micropogonias furnieri and the striped weakfish Cynoscion guatucupa are important coastal resources presenting evidence of overexploitation and stock depletion in the Argentinian-Uruguayan fishing area and off southern Brazil (RUARTE, 2001; RODRIGUEZ et al., 2002).

On the Brazilian coast, incidental franciscana mortality has been estimated from monitoring fisheries' programs and from beach surveys. The latest incidental mortality estimates in this country showed 110 franciscana dolphins bycaught every year in Espírito Santo and Rio de Janeiro (period: 2001-2002, DI BENEDITTO, 2003), 330 in Sao Paulo (period: 1998-1999; ROSAS et al., 2002), 25 in Paraná (period: 1997-1999, ROSAS et al., 2002) and 719-946 in Rio Grande do Sul (period: 1999-2000, SECCHI et al., 2004). Recently, FrancoTrecu et al. (2009) have estimated, for 2006, an annual bycatch mortality in Uruguay of 289 franciscana dolphins, based on a fisheries' monitoring program. However, the methodologies applied in each local area of the species' distribution are different and the biases resulting from the lack of standardized criteria have not been evaluated.

In Argentina, the first estimate of incidental mortality for the franciscana dolphin caused by artisanal fisheries was made almost 30 years ago (PÉREZ-MACRI; CRESPO, 1989). In that period, some 340-350 dolphins were bycaught annually, mainly in $300 \mathrm{~mm}$ mesh size gillnets and "tapacanal" gillnets that blocked estuarial channels. Recently, new estimates have shown that in Argentina, 400-600 franciscana dolphins have been killed every year by artisanal fisheries (BORDINO; ALBAREDA, 2004; CAPPOZZO et al., 2007). However, because of the changing dynamics of fisheries, a re-evaluation of the franciscana dolphin bycatch and the fishing effort involved is necessary over the years. The aim of this paper is, therefore, to estimate the incidental mortality of $P$. blainvillei on the Southern coast of Buenos Aires province (Argentina) for the period 2006-2009, and to compare these results with previous estimates reported for the past 20 years.

\section{Material and Methods}

Since August 2003 we have worked with artisanal fishermen of the Southern coast of Buenos Aires province, Argentina, in the localities of Necochea ( $\left.38^{\circ} 37^{\prime} \mathrm{S}, 58^{\circ} 50^{\prime} \mathrm{W}\right)$, Claromecó (38 $51^{\circ} \mathrm{S}$, $60^{\circ} 4^{\prime} \mathrm{W}$ ), Monte Hermoso (38 $59^{\prime} \mathrm{S}, 61^{\circ} 18^{\prime} \mathrm{W}$ ) and Bahía Blanca ( $\left.38^{\circ} 44^{\prime} \mathrm{S}, 62^{\circ} 16^{\prime} \mathrm{W}\right)$ (Fig. 1). During the first years of the survey (2003-2006) we identified fishermen within the communities who were willing to cooperate with the present study and could be considered trustworthy. After our preliminary survey we only continued working with these fishermen.

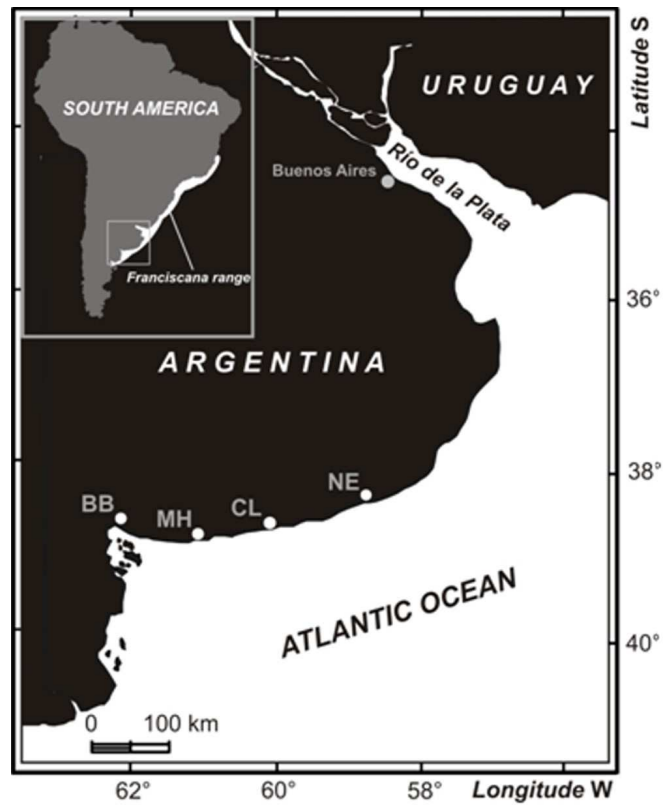

Fig. 1. Study area in Southern Buenos Aires province, Argentina. BB: Bahía Blanca, MH: Monte Hermoso, CL: Claromecó, NE: Necochea.

We thus conducted interviews with the owners and captains of fishing vessels, between 2006 and 2009, to study the seasonal variations in their fishing activities and their interaction with franciscana dolphins. Interviews, equally related to the three survey periods, were carried out over 178 days on which a total of $39-50$ (45-50\%, Table 1) fishing vessels of the artisanal fishing fleet that operated with gillnets and shrimper fishing gear were contacted. The 
interviews were held by one or two researchers who recorded the number of franciscana dolphins bycaught, the fishing gear used and its specifications (mesh size, length), the depth and distance from the shore and the target species of the fishery. In addition, data regarding the number of fishing days in the year and number of active fishing vessels in each survey period were collected.

The interviews were held personally on the beaches and at the fishing camps, harbours or fishermen's homes and generally after the fishing trips. The data concerning the fishing effort were also compared with, completed from and checked against those obtained by the Argentinian Coast Guard (Prefectura Naval Argentina) and personnel of the protected areas in order to gather data in as great detail as possible.

Whenever possible, onboard observations were also made. Unfortunately, it was not possible to make them regularly, thus precluding comparisons with the estimates resulting from the surveys.
In order to compare them with previous estimates for the same study area, incidental mortality (M), fishing effort (FE) and catch per unit of effort (CPUE) were calculated for each locality and kind of fishing gear used, following Corcuera et al. (1994). Annual bycatch (M) for each year, locality and fishing gear were estimated for the whole fleet taking into account the incidental captures reported by the fishermen interviewed. It was assumed that the bycatch rate of the fishing vessels surveyed was equal to that of those not surveyed for the same locality and kind of fishing gear and that it was straightly proportional (CORCUERA et al., 1994). Confidence intervals were calculated from a Poisson distribution model (ZAR, 1996; g CORCUERA et al., 1994):

$\mathrm{CI}_{\text {upper }}(\mathrm{M})=\left[\mathrm{X}_{0.025 ; 2(\mathrm{M}+1)}^{2} / 2 ; \mathrm{CI}_{\text {lower }}(\mathrm{M})=\left[\mathrm{X}_{0.975 ; 2 \mathrm{M}}^{2}\right] / 2\right.$

where $M$ are the estimated incidental captures and $\mathrm{X}^{2}$ the chi-squared value obtained from tables.

Table 1. Description of the artisanal fishing fleet that operated with gillnets and shrimper gear in 2006-2009 in Southern Buenos Aires province, Argentina.

\begin{tabular}{|c|c|c|c|c|c|c|c|c|c|c|c|}
\hline \multirow[b]{2}{*}{ Locality } & \multicolumn{4}{|c|}{ Vessel } & \multirow[b]{2}{*}{ Target species } & \multicolumn{3}{|c|}{ Fishing gear } & \multicolumn{2}{|c|}{ Fishing ground } & \multirow[b]{2}{*}{$\underset{\text { year }^{-1}}{\text { Fishing days }}$} \\
\hline & $\mathrm{n}$ total & $\begin{array}{l}\mathrm{n} \\
\text { surveyed }\end{array}$ & Made of & $\begin{array}{l}\text { Length } \\
(\mathrm{m})\end{array}$ & & Type & Length $(\mathrm{km})$ & $\begin{array}{l}\text { Mesh size } \\
\quad(\mathrm{mm})\end{array}$ & $\begin{array}{l}\text { Distance } \\
\text { offshore } \\
(\mathrm{km})\end{array}$ & Depth (m) & \\
\hline Necochea & 1 & 1 & wood & Up to 13 & \begin{tabular}{|l} 
Mustelus schmitti, \\
Galeorhinus galeus
\end{tabular} & $\begin{array}{l}\text { bottom } \\
\text { gillnet }\end{array}$ & $0.90-2.50$ & 140 & $11.25-22.50$ & $40-50$ & $\begin{array}{l}37 \\
(32-42)\end{array}$ \\
\hline Claromecó & $20-22$ & $11-13$ & fiberglass & $5.8-9.8$ & \begin{tabular}{|l|} 
coastal fish species, \\
Cynoscion guatucupa, \\
Micropogonias furnieri, \\
M. schmitti \\
\end{tabular} & $\begin{array}{l}\text { bottom } \\
\text { gillnet }\end{array}$ & $0.25-1.20$ & $105-330$ & $0.3-30.0$ & $10-30$ & $\begin{array}{l}64 \\
(42-147)\end{array}$ \\
\hline $\begin{array}{l}\text { Monte } \\
\text { Hermoso }\end{array}$ & 25 & $9-10$ & $\begin{array}{l}\text { wood, } \\
\text { fiberglass }\end{array}$ & $5.8-9.8$ & $\begin{array}{l}\text { coastal fish species, } C \text {. } \\
\text { guatucupa, } \\
\text { M. furnieri, } \\
\text { M. schmitti }\end{array}$ & $\begin{array}{l}\text { bottom } \\
\text { gillnet }\end{array}$ & $0.10-2.50$ & $100-110$ & $1-30$ & $8-20$ & $\begin{array}{l}52 \\
(14-84)\end{array}$ \\
\hline \multirow{2}{*}{$\begin{array}{l}\text { Bahía } \\
\text { Blanca }\end{array}$} & 15 & \multirow{2}{*}{$18-26$} & \multirow{2}{*}{ wood } & Up to 13 & \multirow{2}{*}{\begin{tabular}{|l} 
Artemesia longinaris \\
Pleoticus muelleri
\end{tabular}} & \multirow{2}{*}{ Shrimper } & & \multirow{2}{*}{$40-45$} & \multirow[t]{2}{*}{ - } & $4.0-12.8$ & \multirow{2}{*}{$\begin{array}{l}75 \\
(45-180)\end{array}$} \\
\hline & 25 & & & $6-10$ & & & $j^{-}$ & & & $1-4$ & \\
\hline
\end{tabular}

Because of the differences between the two kinds of gear studied, the fishing effort was calculated for each one separately. The gillnet fishing effort was obtained from the number of fishing vessels $(\mathrm{N})$, the mean number of fishing days per annum of each vessel (D) and the mean length of the gillnets set on each fishing trip, in $\mathrm{km}(\mathrm{K})$. The shrimper nets are funnel shaped with walls and a pocket. These nets are set during a stationary tide and taken in again before the next stationary tide. The gear's fishing effort was calculated from the number of fishing vessels $(N)$, the mean number of annual fishing months of each vessel $(\mathrm{m})$, and the number of shrimper nets set on each fishing trip (C). Therefore:

$\mathrm{FE}_{\text {gillnets }}=\mathrm{N} * \mathrm{D} * \mathrm{~K} ; \mathrm{FE}_{\text {shrimpers }}=\mathrm{N} * \mathrm{~m} * \mathrm{C}$
The CPUE was estimated for each kind of gear and each locality and period surveyed. Confidence intervals were calculated from a Poisson distribution model (ZAR, 1996; CORCUERA et al., 1994): $\mathrm{CPUE}=\mathrm{M} / \mathrm{FE}$

$\mathrm{CI}_{\text {upper }}(\mathrm{CPUE})=\left[\mathrm{X}_{0.025 ; 2(\mathrm{c}+1)}^{2} / 2 * \mathrm{FE} ; \mathrm{CI}_{\text {lower }}(\mathrm{CPUE})=\right.$ $\left[\mathrm{X}^{2} 0.975 ; 2 \mathrm{c}\right] / 2 * \mathrm{FE}$

In order to identify the variables that best explain the temporal fluctuations of incidental captures in gillnets (variable response) during the study period, we used a generalized linear model (MCCULLAGH; NELDER, 1999 GLZ) assuming a log link function. The explanatory variables were: number of gillnet fishing days (D), gillnet mesh size (m), gillnets' length $(\mathrm{K})$ and number of fishing vessels $(\mathrm{N})$. The search for 
the best subset of variables was based on the Akaike Information Criterion (AIC), those with the lowest AIC value being the most explicative. Those models with less than two units of difference between their AIC value and the lowest one might be considered equal with high empirical support (BURNHAM; ANDERSON, 2002). All the analyses were performed with the software Statistica 7.0.

In addition, the CPUE values estimated in the period 1992-1993 for the same localities by CORCUERA (1994) and in the period 1998-2003 by CAPPOZZO et al. (2007) were recalculated for each kind of fishing gear in order to permit comparison with our data.

\section{Results}

\section{Description of the fishing activities undertaken} in the study area

Our survey during the study period showed that in Southern Buenos Aires province, artisanal fishery with landing sites in adjacent areas targeted species included in the group known as "coastal diversity" ("variado costero" in Spanish), as defined by Lasta et al. (1999) and FAO (2005). White croacker M. furnieri, striped weakfish $C$. guatucupa, Patagonian smoothhound Mustelus schmitti, and various genera of coastal rays are the species that contribute to most of the landings. The kinds of fishing gear most frequently used in the study area were identified as: bottom gillnet, bottom trawl, shrimpers, traps, longlines and handlines (vertical longlines), in accordance with the definitions of Arias (1988), Nédélec and Prado (1990), and Crespo et al. (1994).

Within the area and period surveyed, franciscana bycatch was reported only for gillnets and shrimper gear. Gillnets were set up to $50 \mathrm{~m}$ deep and $30 \mathrm{~km}$ from the shore, and remained in the sea for from 7 to 24 hours depending on the water temperature. In Table 1 there is a description of kinds of gillnet and shrimper fishing gear, grounds and vessels in each locality surveyed.

Quequén harbour (Necochea) has an operating fleet of almost thirty artisanal wooden fishing vessels (up to $13 \mathrm{~m}$ long) equipped with bottom trawling gear, for which no franciscana dolphin bycatch was observed. The only fishing vessel that used bottom gillnets reported incidental franciscana mortality (Table 1).

In contrast, as no harbours exist in Claromecó, artisanal fishing vessels are launched using trailers and tractors. Around 20-22 vessels operated with bottom gillnets between November and August (Table 1) and using traps in September and October. Further, four vessels of larger dimensions operated with bottom trawls targeting flounders, the Argentine red shrimp Pleoticus muelleri and sea snails (mainly the volute snail Zidona dufresnei).

In Monte Hermoso, only 25 of more than a hundred artisanal vessels operated with gillnets mainly in the shark fishing season from August to November (Table 1). The rest of the fleet targeted coastal fishes with handlines and longlines. All of them operated directly from the beach just as in Claromecó.

Ingeniero White harbour is set on the Bahía Blanca estuary, adjacent to the city of the same name. Most of the estuary is a protected area where the use of trawling gear is forbidden. Artisanal fishery could only be studied in the first two survey periods (20062007 and 2007-2008). In October and November, the fishing fleet was gillnetting Patagonian smoothhound. Later, from December to June each vessel set 6-10 shrimper nets to catch the stiletto shrimp Artemesia longinaris and the Argentine red shrimp P. muelleri (Table 1). From December to the beginning of January shrimp fishing is forbidden - to allow the growth and maturating of these species. In July the target species is the striped weakfish with nets similar to the shrimper but with a pocket of $105 \mathrm{~mm}$ mesh size. A difference was observed at this harbour between the fishing grounds of the smaller and the larger artisanal vessels (Table 1). The incidental mortality was, therefore, estimated separately for these two sizes of vessel (6-10 $\mathrm{m}$ and 10(?)-13 $\mathrm{m}$ long) as the assumption of equal bycatch rates for both classes of vessel would possibly be rejected.

\section{Franciscana dolphin incidental mortality}

During the three periods surveyed, the franciscana dolphin bycatch in gillnets and shrimpers of the southern Buenos Aires province occurred all year round but the higher capture frequencies reported by the vessels monitored were recorded between October and February $\left(\mathrm{X}^{2}\right.$ test, $\left.\mathrm{p}=0.002\right)$. Incidental captures took place at $0.10-30.00 \mathrm{~km}$ offshore (median $=4.50 \mathrm{~km}$, mean $=7.43 \mathrm{~km}, \mathrm{DS}=7.14 \mathrm{~km}, \mathrm{n}=63$ ) and $11-50 \mathrm{~m}$ depth $($ median $=16.50 \mathrm{~m}$, mean $=21.00$ $\mathrm{m}, \mathrm{DS}=11.07 \mathrm{~m}, \mathrm{n}=26$ ). However, $51 \%$ of the captures occurred within $5 \mathrm{~km}$ of the coast and $71 \%$ at 10-20 m depths.

The estimated mean annual franciscana dolphin incidental mortality of Southern Buenos Aires province was 107 dolphins (CI 95\% = 87-129), 92 bycaught in gillnets $(\mathrm{CI} 95 \%=73-112)$ and 15 in shrimpers (CI 95\% = 8-25). Therefore, the resultant CPUE was estimated as 0.029 dolphins per $\mathrm{km}$ of gillnet (CI 95\% $=0.023-0.036)$ and 0.022 dolphins per shrimper net $(\mathrm{CI} 95 \%=0.012-0.035)$.

Annual incidental mortality and CPUE of each locality and period surveyed are detailed in Table 2. 
Table 2. Annual incidental mortality (M), fishing effort (FE) and catch per unit of effort (CPUE) of franciscana dolphin estimated in Necochea, Claromecó and Monte Hermoso by gillnets ${ }^{1}$; and in Bahía Blanca by shrimpers ${ }^{2}$, Southern Buenos Aires province, Argentina, in 2006-2009. Values between brackets correspond to $95 \%$ confidence intervals.

\begin{tabular}{|c|c|c|c|c|c|c|c|c|c|}
\hline & \multicolumn{3}{|c|}{$2006-2007$} & \multicolumn{3}{|c|}{$2007-2008$} & \multicolumn{3}{|c|}{ 2008-2009 } \\
\hline & M & FE & CPUE & M & FE & CPUE & M & FE & CPUE \\
\hline Necochea & \begin{tabular}{|l|}
10.00 \\
$(4.80-18.39)$
\end{tabular} & 80.00 & \begin{tabular}{|l|}
0.13 \\
$(0.06-0.23)$ \\
\end{tabular} & \begin{tabular}{|l}
.00 \\
$(0.24-7.22)$ \\
\end{tabular} & 105.00 & \begin{tabular}{|l|}
0.02 \\
$(0.00-0.07)$ \\
\end{tabular} & \begin{tabular}{|l|}
10.00 \\
$(4.80-18.39)$
\end{tabular} & 105.00 & \begin{tabular}{|l|}
0.10 \\
$(0.05-0.18)$ \\
\end{tabular} \\
\hline Claromecó & \begin{tabular}{|l|}
58.67 \\
$(47.54-79.48)$ \\
\end{tabular} & $1,904.41$ & \begin{tabular}{|l|}
0.03 \\
$(0.03-0.04)$ \\
\end{tabular} & \begin{tabular}{|l|}
37.23 \\
$(26.05-51.00)$ \\
\end{tabular} & $1,554.96$ & \begin{tabular}{|l|}
0.02 \\
$(0.02-0.03)$ \\
\end{tabular} & \begin{tabular}{|l|}
65.00 \\
$(50.17-82.85)$ \\
\end{tabular} & $1,728.00$ & \begin{tabular}{|l|}
0.04 \\
$(0.03-0.05)$ \\
\end{tabular} \\
\hline Monte Hermoso & \begin{tabular}{|l|}
22.22 \\
$(13.79-33.31)$ \\
\end{tabular} & $1,487.50$ & \begin{tabular}{|l|}
0.02 \\
$(0.01-0.02)$
\end{tabular} & \begin{tabular}{|l|}
16.67 \\
$(9.52-26.60)$
\end{tabular} & $1,115.75$ & \begin{tabular}{|l|}
0.02 \\
$(0.01-0.03)$ \\
\end{tabular} & \begin{tabular}{|l|}
52.50 \\
$(39.27-68.76)$ \\
\end{tabular} & $1,280.00$ & \begin{tabular}{|l|}
0.04 \\
$(0.03-0.05)$ \\
\end{tabular} \\
\hline Total gillnets & $\begin{array}{l}90.89 \\
(72.82-111.18)\end{array}$ & $3,471.91$ & $\begin{array}{l}0.03 \\
(0.02-0.03)\end{array}$ & $\begin{array}{l}55.90 \\
(41.87-72.16)\end{array}$ & $2,775.71$ & $\begin{array}{l}0.02 \\
(0.02-0.03)\end{array}$ & $\begin{array}{l}127.50 \\
(106.33- \\
151.65)\end{array}$ & $3,113.00$ & $\begin{array}{l}0.04 \\
(0.03-0.05)\end{array}$ \\
\hline Bahía Blanca & \begin{tabular}{|l|}
11.25 \\
$(13.00-32.10)$ \\
\end{tabular} & 711.44 & \begin{tabular}{|l|}
0.03 \\
$(0.02-0.05)$ \\
\end{tabular} & \begin{tabular}{|l|}
9.56 \\
$(4.45-17.74)$ \\
\end{tabular} & 711.44 & $\begin{array}{l}0.01 \\
(0.01-0.02) \\
\end{array}$ & - & - & - \\
\hline TOTAL & \begin{tabular}{|l|}
112.14 \\
$(92.22-134.77)$
\end{tabular} & & & \begin{tabular}{|l|}
64.45 \\
$(50.17-82.85)$
\end{tabular} & & & - & & \\
\hline
\end{tabular}

${ }^{1}[\mathrm{FE}]=\mathrm{km}$ of gillnets; $[\mathrm{CPUE}]=$ dolphins bycaught $/ \mathrm{km}$ of gillnet.

${ }^{2}[\mathrm{FE}]=$ number of shrimpers, $[\mathrm{CPUE}]=$ dolphins bycaught/shrimper.

In the three seasons surveyed (2006-2009), the only fishing gillnet vessel in Quequén harbour bycaught from 2-10 franciscana dolphins per year (mean $=7$, CI $95 \%=3-14$ ) with a FE of $96.7 \mathrm{~km}$ of gillnets set annually and CPUE of 0.076 bycaught dolphins p.a. and $\mathrm{km}$ of gillnet (CI 95\% $=0.059$ 0.095).

In Claromecó, fluctuations in fishing days occurred throughout the survey and, consequently, in the fishing effort expended. As could be observed during this study, a reduction in the number of fishing days was related to adverse meteorological conditions and economic consequences (i.e. low demand and increased fuel costs during late 2008) (Table 1). Fluctuations have also been registered in the number of incidental captures. In particular, during the period 2008-2009, two fishing vessels increased the mesh size of their gillnets to $330 \mathrm{~mm}$ and were responsible for $40 \%$ of the annual captures. Consequently, mean annual incidental mortality estimated for this locality was of 54 dolphins (CI 95\% $=40-70$ ) with a CPUE of 0.031 dolphins per $\mathrm{km}$ of gillnet $($ CI 95\% $=0.021-0.044)$.

The meteorological conditions at Monte Hermoso also determined the number of fishing days in the year, especially in 2007-2008. However, the decline in the number of fishing days was also a consequence of the damage that the southern sea lion Otaria flavescens caused to gillnets and trapped fish. In order to avoid this problem, fishermen changed their fishing gear from gillnets to longlines and handlines to reduce the economic loss. Mean annual mortality was estimated at 30 dolphins for gillnets (CI $95 \%=20-43)$ and a CPUE of 0.024 dolphins per $\mathrm{km}$ of net $(\mathrm{CI} 95 \%=0.016-0.033)$.
At all the three localities mentioned above, fishing effort was the determinant of the variations in franciscana bycatch in gillnets, with a high positive correlation (Spearman rank correlation, $\mathrm{R}=0.985 ; \mathrm{p}=$ 0.001). Particularly, of the variables that determined the fishing effort, the number of annual fishing days showed the highest positive correlation with incidental mortality in gillnets (Spearman rank correlation, $\mathrm{R}=$ 0.912; $\mathrm{p}<0.001)$.

Furthermore, the generalized linear model suggested that the variables involved in the fishing effort and mesh size showed the lowest AIC values in the following combinations: $\mathrm{AIC}_{\mathrm{D}}=50.71 ; \mathrm{AIC}_{\mathrm{D}-\mathrm{m}}=$ $52.07 ; \mathrm{AIC}_{\mathrm{D}-\mathrm{N}}=52.59 ; \mathrm{AIC}_{\mathrm{D}-\mathrm{K}}=52.60(\mathrm{GLZ}, \mathrm{p}<$ 0.001). All these combinations of variables would equally well explain the fluctuations of incidental franciscana captures in the study area.

On the other hand, at Ingeniero White harbour the number of fishing days and vessels showed no variation throughout the survey, thus the fishing effort also remained constant $(\mathrm{FE}=711.44$ nets/year). Between 2006 and 2008, 15 franciscana dolphins were estimated to have been bycaught annually (CI 95\% = 8-25) with a mean annual associated CPUE of 0.022 dolphins per shrimper net $($ CI $95 \%=0.012-0.035)$. In particular, 9 franciscanas were estimated to have been bycaught by the larger vessels $(\mathrm{CI} 95 \%=4-17$; $\mathrm{CPUE}=0.032$, CI 95\% $=$ $0.014-0.060)$ and 6 by the smaller ones (CI 95\% $=2$ $13 ;$ CPUE $=0.015$, CI 95\% $=0.005-0.031)$.

Finally, Figures 2 and 3 show the current fishing effort and CPUE estimates (2006-2009, this study) as compared with previous ones of Southern Buenos Aires province (CORCUERA, 1994; CAPPOZZO et al., 2007). In the period 1992-1993, 
the artisanal fleet operated with gillnets of 180-360 $\mathrm{mm}$ mesh size targeting tope sharks, with a franciscana bycatch of 130 dolphins in gillnets and 85 in shrimper gear (CORCUERA, 1994). Later, since 1998, fisheries started to capture species of the coastal variety with gillnets of $90-220 \mathrm{~mm}$ mesh size that incidentally killed 51 franciscanas in gillnets and 83 in shrimper gear (CAPPOZZO et al., 2007). The period 2002-2003 was similar to the one studied in this paper in relation to fishing grounds, practices and target species (CAPPOZZO et al., 2007). In this last period, the incidental mortality was of 15 dolphins in gillnets and 48 in shrimper gear.

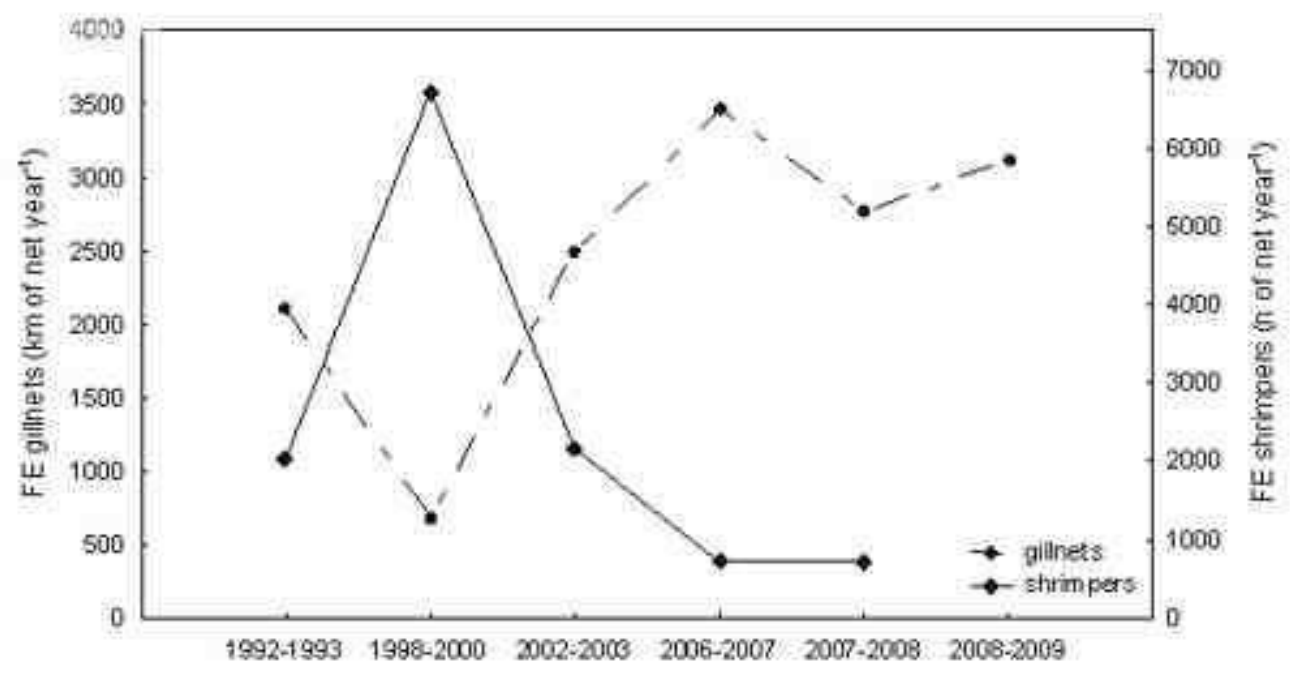

Fig. 2. Annual gillnet and shrimper fishing effort off Southern Buenos Aires over time: 1992-1993= CORCUERA (1994); 1998-2003 = CAPPOZZO et al. (2007); 2006-2009 = this study.

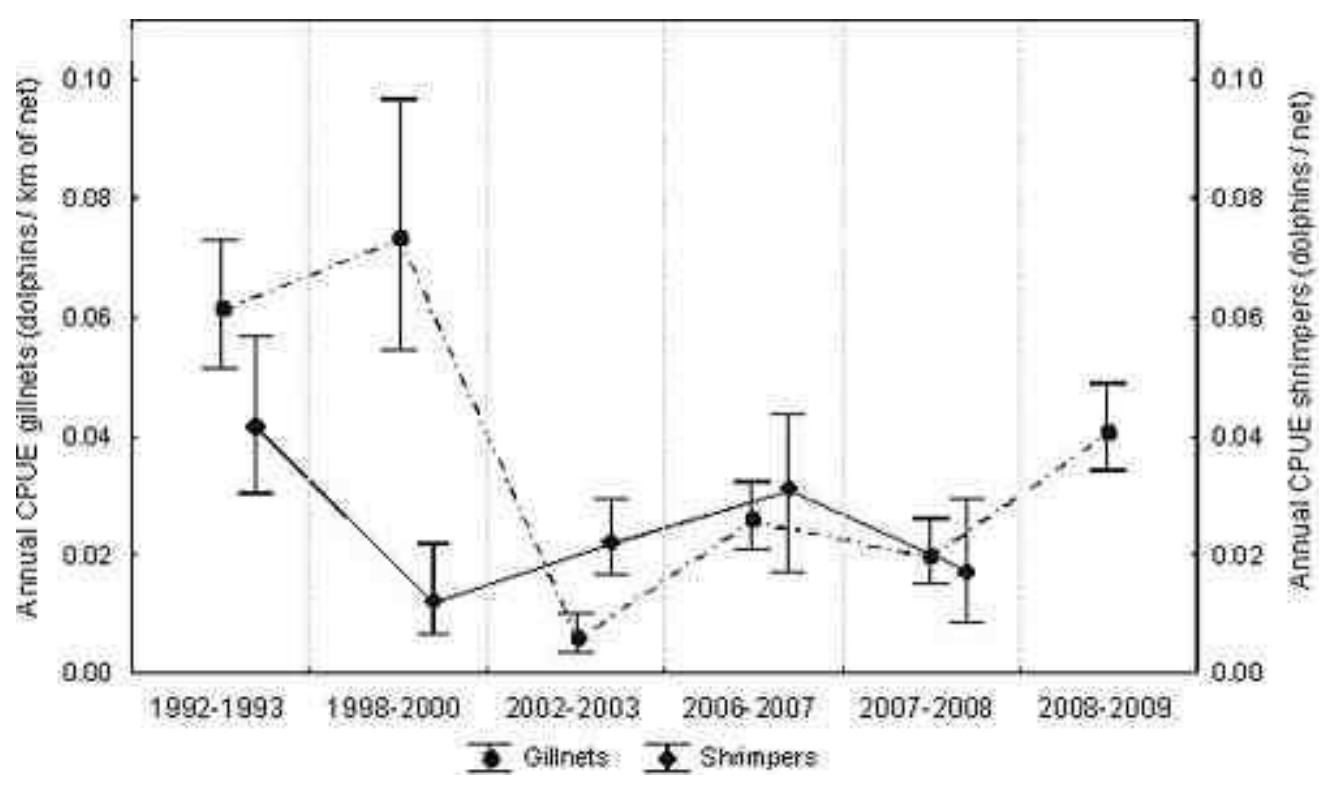

Fig. 3. Annual catch per unit of effort (CPUE) of franciscana dolphins in gillnets and shrimpers off Southern Buenos Aires over time: 1992-1993 = CORCUERA (1994); 1998-2003 = CAPPOZZO et al. (2007); 2006$2009=$ this study. Vertical bars correspond to $95 \%$ confidence intervals. 


\section{DisCUSSION}

Despite onboard observations' continuing to be the most accurate methodology for bycatch estimation, it is not always feasible with artisanal fisheries because of the small size of the vessels concerned. Most of the literature concerning incidental mortality of small cetaceans in gillnets has, therefore, been based on interviews with fishermen (D'AGROSA et al., 1995; DAWSON, 1991; BAIRD et al., 2002; BELDEN, 2007). In this study, the uninterrupted contact with fishermen throughout the years has generated a reliable source of data that has permitted an accurate estimate of the franciscana bycatch. However, all estimates must be considered as minima not only because of the possible unreported captures but also due to those entangled dolphins that may fall from the nets before or during the hauling-in process and not have been seen by the fishermen or other onboard observers (SECCHI et al., 2004; TREGENZA et al, 1997).

Not all types of fishing gear have the same impact on cetaceans and the risk associated with them also depends on the way they are used (FORTUNA et al., 2010). In Southern Buenos Aires province, the types of fishing gear that were involved in franciscana bycatch in the period studied were bottom gillnets and shrimpers. Further, annual fluctuations in incidental mortality estimates in the localities surveyed were mainly due to differences in the number of gillnet fishing days as a consequence of socioeconomic problems and adverse meteorological conditions. In addition, as stated above, gillnet fishing days have also diminished due to the negative interactions with Southern sea lions. These pinnipeds have a detrimental impact on gillnets and the fish caught, to the point where fishermen from Monte Hermoso are forced to change to longlines and handlines. The same behaviour has also been reported for sea lions of other South American fisheries such as the Uruguayan and Chilean ones (SZTEREN; PÁEZ, 2002; SEPÚLVEDA et al., 2007). Moreover, further studies should include such physical parameters as water temperature in their analyses. In Claromecó, after the fish market was reactivated in February 2009, the franciscana bycatch showed no increase and this could be related to the smaller number of franciscana sightings in those months due to the lower water temperature $\left(18-20^{\circ} \mathrm{C}\right)$ than in the previous summer $\left(24^{\circ} \mathrm{C}\right)$. Variation in water temperature likely affects the seasonal distribution and availability of prey for the franciscana and would explain the general movements of franciscana dolphins in the study area (BORDINO et al., 2002; BORDINO et al., 1999).

On the other hand, shrimper gear is still a threat for franciscanas in the Bahía Blanca estuary. The reduction observed in estimated mortality as compared with that reported in previous studies was related to a lower fishing effort. In addition, fluctuations in the incidental captures could be due to the differences in the fishing grounds of each particular vessel (depth and distance offshore where shrimper gear was set) or differences in franciscana movements within the estuary over the years. Thus, studies related to the population dynamics and habitat use of the franciscana dolphin inside the estuary of Bahía Blanca should urgently be undertaken in order to ascertain the actual causes of the incidental mortality.

Reeves et al. (2003) have postulated that incidental mortality of franciscana dolphins seems to be relatively constant over time, independently of the decrease in some fishing stocks. However, the results of bycatch in Southern Buenos Aires province might not accord with this: Cappozzo et al. (2007) noted a significant reduction in the CPUE of the franciscana dolphin after the tope shark fisheries collapsed at the end of ' 90 at Necochea and Quequén harbours (CHIARAMONTE, 1998). That was why the fishermen moved their fishing grounds further off shore and replaced gillnets by trawls. Thus, when similar fishing operations and conditions are maintained, incidental mortality does not fluctuate (CAPPOZZO et al., 2007) and the estimated mortality and CPUE of this present study (2006-2009) for the Southern coast of the province did not show any considerable variations during the period surveyed.

In comparison with estimates of the 20022003 period (CAPPOZZO et al., 2007), the increase in the incidental mortality described here was mainly a consequence of the increase in the fishing effort owing to the greater number of fishing vessels and longer gillnets. This has been confirmed by the analyses made (SPEARMAN, GLZ) that also evidence the importance of mesh size in the incidental captures of franciscanas in the area. In addition, as the fishing practices of these two periods were similar, the CPUE values might be used as an index of the relative density of the species in the area. In the light of the results of greater fishing effort and higher mortality, the increment of the CPUE values $\left(\mathrm{CPUE}_{2002-2003}=\right.$ 0.006 dolphins $/ \mathrm{km}$ of gillnet; $\mathrm{CPUE}_{2006-2009}=0.029$ dolphins/km of gillnet, Fig. 3) would certainly indicate that the density of franciscana dolphins in the area did not diminish during the period. On the other hand, as the fishing practices of the previous periods (19921998) were different, the CPUE might not be a valid index of relative density.

In relation to capture distribution, the majority of the captures took place within $10 \mathrm{~km}$ of the shore and at less than $20 \mathrm{~m}$ depth, which is in agreement with the results of previous reports for this study area (CORCUERA, 1994). 
The Northern coast of Buenos Aires province has shown higher values of incidental captures (231-410 dolphins; CAPPOZZO et al., 2007, BORDINO; ALBAREDA, 2004, respectively) than those estimated for the southern coast (CAPPOZZO et al., 2007, BORDINO; ALBAREDA, 2004; this study). This might be related to differences between the fishing grounds and patterns of habitat use by the species in the two areas. The shallow waters of the bays (3-12 m deep) of Northern Buenos Aires might increase the encounter rate between dolphins and nets. Moreover, the distances offshore where gillnets are set on the northern coast are shorter than those on the southern coast (0.2-7.0 km vs. 1-30 km, respectively; BORDINO; ALBAREDA, 2004; this study). It is, thus, urgent that comparative research should be undertakn into the patterns of habitat use of franciscana in these two distinct areas.

Mortality estimations can only be included in management programs if they are related to the total abundance of the species. This allows the evaluation of the actual impact of fishing activities on the conservation of the species (FORTUNA et al., 2010). The International Whaling Commission stated that for small cetaceans a bycatch representing $1 \%$ of their population is a matter of conservation concern, and an annual incidental capture of more than $2 \%$ is not sustainable.

In the attempt of arrive at an overall estimate of franciscana incidental mortality in Argentina, combining the latest estimates for the northern coast with those obtained for the southern coast by this current study would certainly lead to bias and underestimation. Although this method might justify reservations, the information given is to date all that is available and in all probability provides us with a valid approximation which may be used for management purposes in the absence of more accurate data.

It is, therefore, strongly recommended that future research into the overall distribution of Argentinian species be undertaken applying one and the same methodology in order to diminish any possible bias in the bycatch rate of franciscana dolphins.

Thus, in the light of the estimates for the northern coast, the annual incidental mortality by bycatch of franciscana in the entire Buenos Aires province would amount to 360-539. As no incidental mortality is registered south of Buenos Aires province, these values represent $2.5-3.7 \%$ of the species abundance in Argentina $(\mathrm{N}=14,645$ dolphins: CRESPO et al., 2010). Moreover, this bycatch rate exceeds the $50 \%$ of franciscana maximum growth rate that would be acceptable $(2-3.7 \%$, SECCHI; FLETCHER, 2004). In consequence, the current bycatch rates will, if maintained, lead to the decline of the Argentinian franciscana dolphin population in the near future.

In addition, recent studies based on mathematical modelling have indicated that franciscanas off Southern Brazil and Uruguay are declining due to unsustainable incidental mortality levels suggesting that the species might be facing the highest risk of extinction of any cetacean of the Southwestern Atlantic Ocean (SECCHI, 1999; SECCHI et al., 2001, 2003; KINAS, 2002).

The conservation strategy for the franciscana depends on political decisions as well as on biological information (CRESPO et al., 2010). Argentinian fishery management policies must be improved; the identification of alternative fishing grounds and types of gear is of the utmost urgency, and the dissemination of the educational programs proposed by the International Whaling Commission should be continued (REEVES et al., 2003). Despite the bycatch problem's including not only scientific aspects and fronts but also social and economic ones, the study of the behavior and ecology of the species involved is the first step in the attempt to reduce the incidental captures (SOYKAN et al., 2008). Thus, it is hoped that the results here presented will represent an essential, basic element in the effort to reduce the bycatch of the franciscana dolphin in our country.

\section{AcKNOWLEDGMENTS}

This study would not have been possible without the unconditional collaboration of the artisanal fishing communities of Southern Buenos Aires; we are, therefore, indebted to all of them. Many people collaborated with the field work and we wish to thank: M.N. Paso Viola, F. Pérez, M.S. Negri, R. Gutiérrez, D. del Castillo, V. Di Martino, M. Dassis, G. Giardino, L. Fainburg and A. Mandiola. We also want to thank the parkrangers and personnel of the protected areas of the region: M. Sotelo, M.V. Massola and A. Areco; and to the technicians of the Estación Hidrobiológica de Puerto Quequén: K. Arias and L. Nogueira. Thanks are also due to $\mathrm{R}$. Bastida who read an earlier version of the manuscript and improved it with his comments and suggestions. A. Zerbini and D. Danilewicz were of great help in discussing methodologies and conclusions. In addition, we are grateful to $\mathrm{L}$. Campagna for his help with the English language and to two anonymous reviewers of the manuscript for their helpful corrections and suggestions. This research project was part of María Fernanda Negri's $\mathrm{PhD}$ thesis for which the Consejo Nacional de Investigaciones Científicas y Técnicas (CONICET) granted her a postgraduate fellowship. Financial support was given by the University of Valencia, Yaqu Pacha, Fundación de Historia Natural Félix de Azara, 
Cetacean Society International, Society for Marine Mammalogy and Universidad Nacional de Mar del Plata (15/E271).

\section{REFERENCES}

ARIAS, P. Artes y métodos de pesca en aguas continentales de América Latina. COPESCAL Doc. Ocas., v. 4, 1988. $178 \mathrm{p}$,

BAIRD, R. W.; STACEY, P. J.; DUFFUS, D. A LANGELIER, K. M. An evaluation of gray whale (Eschrichtius robustus) mortality incidental to fishing operations in British Columbia, Canada. J. Cetacean Res. Manage., v. 4, n. 3, p. 289-296, 2002.

BASTIDA, R.; RODRÍGUEZ, D.; SECCHI, E; DA SILVA, V. Mamíferos Acuáticos de Sudamérica y Antártida. Buenos Aires: Vázquez Mazzini Ed., 2007. 368 p.

BEARZI, G. Interactions between cetacean and fisheries in the Mediterranean Sea. In: NOTARBARTOLO DI SCIARA, G. (Ed.), Cetaceans of the Mediterranean and Black Seas: state of knowledge and conservation strategies. A report to the ACCOBAMS Secretariat, Mónaco, 2002. p. 1-209.

BELDEN, D. Estimates of cetacean and pinniped bycatch in the 2005 northeast sink gillnet and mid-Atlantic coastal gillnet fisheries.U. S. Dep. Commer., Northeast Fishery Science Centre Ref. Doc. 07-08, 16 p, 2007.

BORDINO, P.; THOMPSON, G.; IÑIGUEZ, M. Ecology and behaviour of the franciscana (Pontoporia blainvillei) in Bahía Anegada, Argentina. J. Cetacean Res. Manage., v. 1, n. 2, p. 213-222, 1999.

BORDINO, P.; SICILIANO, S.; BASTIDA, R.; CREMER, M. Report of the working group on distribution and behaviour. Lat. Am. J. Aquat. Mamm., v. 1, n. 1, p. 21 23, 2002.

BORDINO, P.; ALBAREDA, D. Incidental mortality of franciscana dolphin Pontoporia blainvillei in coastal gillnet fisheries in Northern Buenos Aires, Argentina. In: INT. WHAL. COMMN. MEETING, Sorrento, Italy. 2004. (Paper SC/56/SM1).

BURNHAM, K. P.; ANDERSON, D. R. Model Selection and Multimodel Inference: A Practical InformationTheoretic Approach. Second edition. New York, USA: Springer-Verlag, 2002

CAPPOZZO, H. L; NEGRI, M. F; PÉREZ, F. $\mathrm{H}$; ALBAREDA, D.; MONZÓN, F.; CORCUERA, J. F. Incidental mortality of franciscana dolphin, (Pontoporia blainvillei) in Argentina. Lat. Am. J. Aquat. Mamm., v. 6, n. 2, p. 127-137,2007.

CHIARAMONTE, G. E. Shark fisheries in Argentina. Mar. Freshwater Res., v. 49, n. 7, p. 601-609, 1998.

CORCUERA, J. Incidental mortality of franciscanas in argentine waters: the threat of small fishing camps. Rep. Int. Whal. Commn., v. 15, p. 291-294, 1994.

CORCUERA, J.; MONZÓN, F.; CRESPO, E. A. AGUILAR, A.; RAGA, J. A. Interactions between marine mammals and the coastal fisheries of Necochea and Claromecó (Buenos Aires Province, Argentina).Rep. Int. Whal. Commn., v. 15, p. 283-290, 1994

CRESPO, E. A ; CORCUERA, J. F.; LÓPEZ CAZORLA, A Interactions between marine mammals and fisheries in some coastal fishing areas of Argentina. Rep. Int. Whal. Commn., v. 15, p. 269-281, 1994.
CRESPO, E. A.; HARRIS, G.; GONZÁLEZ, R. Group size and distributional range of the franciscana Pontoporia blainvillei. Mar. Mammal Sci., v. 14, n. 4, p. 845-849, 1998.

CRESPO, E. A.; PEDRAZA, S. N.; GRANDI, M. F.; DANS, S. L.; GARAFFO, G. V. Abundance and distribution of endangered franciscana dolphins in argentine waters and conservation implications. Mar. Mammal Sci., v. 26, n. 1, p. 17-35, 2010.

D'AGROSA, C.; VIDAL, O.; GRAHAM, W. C. Mortality of the vaquita (Phocoena sinus) in gill net fisheries during 1993-94. Rep. Int. Whal. Commn., v. 16, p. 283291,1995 .

DAWSON, S. Incidental catch of Hector's dolphins in inshore gillnets. Mar. Mammal Sci., v. 7, n. 3, p. 283295,1991.

DI BENEDITTO, A. P. M. Interactions between gillnet fisheries and small cetaceans in northern Rio de Janeiro, Brazil: 2001-2002. Lat. Am. J. Aquat. Mamm., v. 2, n. 2, p. 79-86, 2003.

FAO. Resumen informativo sobre la pesca por países. La República Argentina. Food and Agriculture Organization of the United Nations FID/CP/ARG. 2005.

FORTUNA, C. M.; VALLINIA, C.; FILIDEI Jr., E.; RUFFINO, M.; CONSALVO, I.; DI MUCCIOA, S.; GION, C.; SCACCO, U.; TARULLI, E.; GIOVANARDI, O.; MAZZOLA A. By-catch of cetaceans and other species of conservation concern during pair trawl fishing operations in the Adriatic Sea (Italy). Chem. Ecol., v. 26, p. 65-76, 2010.

FRANCO-TRECU, V.; COSTA, P.; ABUD, C.; DIMITRIADIS, C.; LAPORTA, P.; PASSADORE, C.; SZEPHEGY, M. By-catch of franciscana Pontoporiablainvillei in uruguayan artisanal gillnet fisheries: an evaluation after a twelve-year gap in data collection. Lat. Am. J. Aquat. Mamm., v. 7, n. 1-2, p. 11-22, 2009.

IÑIGUEZ, M. A.; HEVIA, M.; GASPARROU, C.; TOMSIN, A. L.; SECCHI, E. R.Preliminary estimate of incidental mortality of Commerson's dolphins (Cephalorhynchus commersonii) in an artisanal setnet fishery in La Angelina beach and Ría Gallegos, Santa Cruz, Argentina. Lat. Am. J. Aquat. Mamm., v.2, n. 2, p. 8794, 2003.

KINAS, P. G. The impact of incidental kills by gill nets on the franciscana dolphin (Pontoporia blainvillei) in southern Brazil. B. Mar. Sci., v. 70, n. 2, p. 409-421, 2002.

LASTA, C. A.; CAROZZA, C. R.; RUARTE, C. O.; JAUREGUIZAR, A. J. Ordenamiento pesquero en el ecosistema costero bonaerense. Mar del Plata, Buenos Aires: Technical report INIDEP 25, 1999. 20 p.

MANGEL, J.;ALFARO-SHIGUETO, J.; VAN WAEREBEEK, K.; CACERES, C.; BEARHOP, S.; WITT, M. J.; GODLEY, B. J. Small cetacean captures in peruvian artisanal fisheries: high despite protective legislation. Biol. Conserv., v. 143, p. 136-143, 2010.

MCCULLAGH, P.; NELDER, J. Generalized Linear Models. Second Edition. Boca Raton, USA: Chapman and Hall/CRC, 1999. $511 \mathrm{pp}$.

NÉDÉLEC, C.; PRADO, J. Definición y clasificación de las diversas categorías de artes de pesca.FAO Fisheries Technical Paper. No. 222. Revision 1, 92 p. 1990. 
PÉREZ MACRI, G.; CRESPO, E. A. Survey of the franciscana, Pontoporia blainvillei, along the Argentine coast, with a preliminary evaluation of mortality in coastal fisheries. Occasional papers IUCN SSC, v. 3, p. 57-63, 1989.

PERRIN, W. F.; DONOVAN, G. P.; BARLOW, J. Report of the workshop on mortality of cetaceans in passive fishing nets and traps. Rep. Int. Whal. Commn., v. 15, p. 6-57, 1994.

READ, A. J. Incidental catches of small cetaceans. In: SIMMONDS, M. P.; HUTCHINSON, J. D. The conservation of whales and dolphins: Science and practice. Chichester: John Wiley \& Sons, 1996. p. 109118.

REEVES, R.; LEATHERWOOD, S. Dolphins, porpoises, and whales: 1994-1998 action plan for the conservation of cetaceans. Gland, Switzerland: International Union for the Conservation of Nature, 1994. 92 p.

REEVES, R. R.; SMITH, B. D.; CRESPO, E. A.; NOTARBARTOLO DI SCIARA, G. Dolphins, whales and porpoises: 2002-2010 conservation action plan for the world's cetaceans. Gland, Switzerland and Cambridge: International Union for the Conservation of Nature, 2003. 139 p.

REEVES, R. R.; DALEBOUT, M. L.; JEFFERSON, T. A. KARCZMARSKI, L.; LAIDRE, K.; O'CORRYCROWE, G.; ROJAS-BRACHO, L.; SECCHI, E. R.; SLOOTEN, E.; SMITH, B. D.; WANG, J. Y.; ZERBINI, A. N.; ZHOU, K. Pontoporia blainvillei. In: IUCN 2010. IUCN Red List of Threatened Species. 2008.

RODRÍGUEZ, D.; RIVERO, L.; BASTIDA, R. Feeding Ecology of the Franciscana (Pontoporia blainvillei) in marine and estuarine waters of Argentina. Lat. Am. J. Aquat. Mamm., v. 1, n. 1, p. 77-94, 2002.

ROSAS, F. C. W.; MONTEIRO-FILHO, E. L. A.; OLIVEIRA, M. R. de. Incidental catches of franciscana (Pontoporia blainvillei) on the Southern coast of São Paulo State and the coast of Paraná State, Brazil. Lat. Am. J. Aquat. Mamm., v. 1, n. 1, p. 161-167, 2002.

RUARTE, C. Resultados de distribución de juveniles de pescadilla en la campaña de invierno EH-07-01, con relación al área de la veda estival. Informe Técnico INIDEP, 2001. $8 \mathrm{p}$.

SECCHI, E. R. Taxa de crescimento potencial intrínseco de um estoque de franciscanas, Pontoporia blainvillei (Gervais and D'Orbigny, 1846) (Cetacea, Pontoporiidae) sob o impacto da pesca costeira de emalhe. 1999. 152 p. Master Thesis - Fundação Universidade Federal do Rio Grande, RG, Brazil.

SECCHI, E.R.; FLETCHER, D. Estimating survival rates of franciscana by fitting the Siler model to data on age-at death of beachcast and bycatch and by a modeling approach using life tables of similar species: a comparison. Int. Whal. Commn. Scientific Committee Paper SC/56/SM16. 2004
SECCHI, E. R ; OTT, P. H ; CRESPO, E A.; KINAS, P. G.; PEDRAZA, S. N.; BORDINO, P. A first estimate of franciscana (Pontoporia blainvillei) abundance off southern Brazil. J. Cetacean Res. Manage., v. 3, n. 1, p. 95-100, 2001.

SECCHI, E. R.; DANILEWICZ, D.; OTT, P. H. Applying the phylogeographic concept to identify franciscana dolphin stocks: implications to meet management objectives. J. Cetacean Res. Manage., v. 5, n. 1, p. 6168, 2003.

SECCHI, E. R.; KINAS, P. G.; MUELBERT, M. Incidental catches of Franciscana in coastal gillnet fisheries in the Franciscana Management Area III: period 1999-2000.

Lat. Am. J. Aquat. Mamm., v. 3, n. 1, p. 61-68, 2004.

SEPÚLVEDA, M.; PÉREZ, M.; SIELFELD, W.; OLIVA, D; DURÁN, L; RODRÍGUEZ, L.; ARAOS, V.; BUSCAGLIA, M. Operational interaction between south american sea lions Otaria flavescens and artisanal (small-scale) fishing in Chile: results from interview surveys and onboard observations. Fish. R., v. 83, p. 332-340, 2007.

SHIGUETO, J.A.; MANGEL, J.C.; VAN WAEREBEEK, K. Small cetacean captures and CPUE estimates in artisanal fisheries operating from a port in northern Peru, 20052007. Paper SC/60/SM19 presented to IWC Scientific Committee Meeting, 2008.

SICILIANO, S. Review of small cetaceans and fishery interactions in coastal waters of Brazil. Rep. Int. Whal. Commn., v. 15, p. 241-250, 1994.

SOYKAN, C.U.; MOORE, J.E.; NAS ÎYDELIS, R.; CROWDER, L.B.; SAFINA, C.; LEWISON, R.L. Why study bycatch? An introduction to the Theme Section on fisheries bycatch. Endang. Species Res., v. 5, p. 91-102, 2008 .

SZTEREN, D.; PAEZ, E. Predation by southern sea lions (Otaria flavescens) on artisanal fishing catches in Uruguay. Mar. Fresh. Res., v. 53, n. 8, p. 1161-1167, 2002.

TREGENZA, N. J. C.; BERROW, S. D.; HAMMOND, P. S.; LEAPER, R. Harbour porpoise (Phocoena phocoena L.) by-catch in set gillnets in the Celtic Sea. ICES J. Mar. Sci., v. 54, p. 896-904, 1997.

ZAR, J. H. (ed.) Biostatistical Analysis. New Jersey: Prentice-Hall Inc., 1996.662 p.

(Manuscript received 28 February 2011; revised 05 April 2012; accepted 18 April 2012) 